\title{
LASZLO M. PALOTAS ELÖADÁSA AZ ÁTADÓ ÜNNEPSÉGEN
}

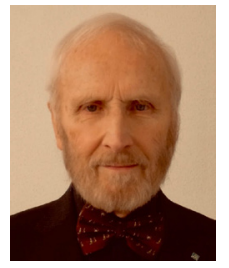

Prof. Dr.-Ing. Laszlo M. Palotas, Ph.D.

Mélyen tisztelt Elnök Úr, tisztelt Hölgyeim és Uraim, kedves ünneplö vendégek!

Köszönetemet fejezem ki a fib Magyar Tagozatának, különösen a fib Magyar Tagozata Elnökének, Balázs L. György professzornak, hogy ebben az évben is részese lehetek a Palotás László-díj átadási ünnepségének.

Szeretettel köszöntöm díjazottjainkat, Karakas János okl. épitömérnököt, az FBE Kft. ügyzetö igazgatóját, Varga András okl. építőmérnököt, a WHB Kft. területi igazgatóját valamint dr. Kaszás Károly professzort, az Újvidéki Egyetem, Szabadkai Építőmérnöki Kar nyugalmazott egyetemi tanárát Szerbiából.

Az elmult évben tartott bevezetömben többek között a genovai Polcevera-viadukt (Morandi-hid) 2018. augusztus 14-én bekövetkezett tragikus összeomlásával foglalkoztam (1. ábra).

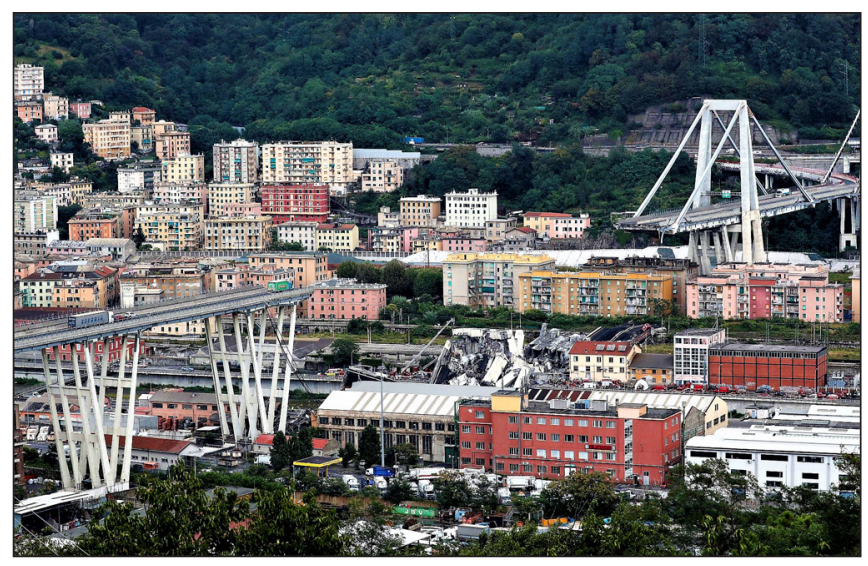

1. ábra: A Morandi hid az összeomlás után, Genova

A Morandi-hidat 1967-ben „mint remekmüvet” adták át a forgalomnak.

„Egyáltalán nem remekmü, egy mérnöki kudarc.” (Macché capolavoro, è un fallimento dell'ingegneria)

Így jellemezte Antonio Brencich, a genovai Építőmérnöki Kar vasbeton szerkezetek professzora 2016 májusában, két évvel a híd összeomlása elött - a Primo Canale televízióval folytatott interjúban - a Morandi hidat. Már ebben az évben megjósolta, hogy a híd össze fog dölni:

„Mint mondtam, és a tények megalapozták, hogy az ilyen típusú híd rosszul van megtervezve, és rosszul kiszámítva, és nyilvánvaló sebezhetőségi problémákkal rendelkezik. Végül is, ha csak három van a világon, akkor ennek van oka”.

("Dicevo, e i fatti mi stanno dando ragione, che quella tipologia di ponti è mal progettata e mal calcolata, e ha evidenti problemi di vulnerabilità. Del resto, se ce ne sono solo tre in tutto il mondo, un motivo ci sarà»)
Ma tudjuk, hogy a három hídból csak egy van használatban. Egyébként a Corriere della Sera napilap szerint 2013. óta ez volt a 11. hídkataszrófa Olaszországban.

Brencich következtetése Riccardo Morandi építészről ugyanolyan világos, mint végzetes volt:

\section{„Egy nagy intuícióval, de kevés számitási gyakorlattal rendelkezö mérnök volt”.}

Az igazsághoz viszont az is hozzátartozik, hogy Brencich professzor, akit a katasztrófa után a vizsgáló bizottság vezetésével biztak meg, egy héttel kinevezése után lemondott, mivel állítólag kiderült, hogy 2018-ban aláírt egy jelentést, ami még nem tartotta szükségesnek a Morandi-híd lezárását.

Most felmerül a kérdés: mi történt időközben az eltelt 16 hónap alatt? E kérdés válaszában szeretném bemutani az utóbbi évtizedek két legjelentősebb sztárépitészének Renzo Piano és Santiago Calatrava néhány alkotását is.

2019 április elején hivatalosan meghirdettek egy versenypályázatot a híd újjáépítéséhez. A genovai, összeomlott Morandi-híd rekonstrukciós biztosa - Marco Bucci, Genova polgármestere - által felállított csoport számos jó építész terveit vizsgálta meg, köztük a két előzőekben említett sztárépitész, Piano és Calatrava terveit.

A héttagú csoport egyetemi tanárokból, mérnökökből, építészekből, szakemberekből és városi tisztviselőkből állt. Minden tag független volt az újjáépítésben részt vevő versenytársaktól, és ingyenesen nyújtották szakértelmüket.

Végül is Marco Bucci úgy döntött, hogy a Salini Impregilo építőipari társaság, valamint az állami ellenőrzés alatt álló Fincantieri és ItalFerr társaságok építik fel az új hidat Renzo Piano vezetése alatt a kikötő városában. Az újjáépítés 202 millió euróba fog kerülni. Kifejezetten kizárták a munkákból az autópálya-üzemeltető „Autostrade per l'Italia” -t, amelyet az Benetton család csoportja irányít. „, A mai nap fontos lépés a város jövője szempontjából, 2019. végéig az új híd átadására sor fog kerülni" - mondta Bucci 2019. december 19-én este Genovában.

E döntésnek viszont van egy kis szépséghibája: Marco Bocci ugyanis már 2018. decemberében döntött Renzo Piano személye mellett! Építőmérnökök és építészek egyesülete, egyetemi oktatók és a Nápolyi Építészkamara elnöke se nézte jó szemmel, hogy Renzo Pianot tulajdonképpen verseny nélkül bízták meg az újjáépítés vezetésével.

Tekintettel a sok logisztikai és bürokratikus akadályra, Bucci terve azonban túl optimistának tünt. Az új határidőt, 2020. áprilisát legutóbb Danilo Toninelli közlekedési miniszter határozta meg.

Az új híd tervezője tehát a 81 éves, Genovából származó sztárépítész Renzo Piano lett. Mielőtt azonban a Pritzker 
Építészeti-díjas sztárépítész megkezdhettte volna az ujjáépítést - az 1,2 kilométeres régi híd többi részét - ami részben sűrün lakott területen vezet át - le kellett bontani, és nem lehetett egyszerüen felrobbantani. Feldarabolva és hatalmas darukkal kellett elszállitani a 40 méter magasságban lévö hid darabjait (2. ábra).

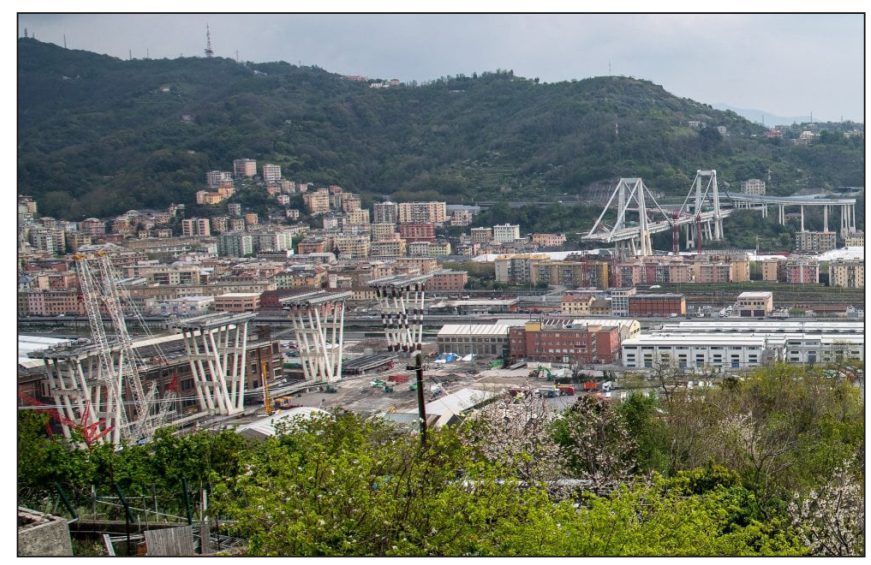

2. ábra: A feldarabolt Morandi hid (c) Roberto Orlando/la Repubblica

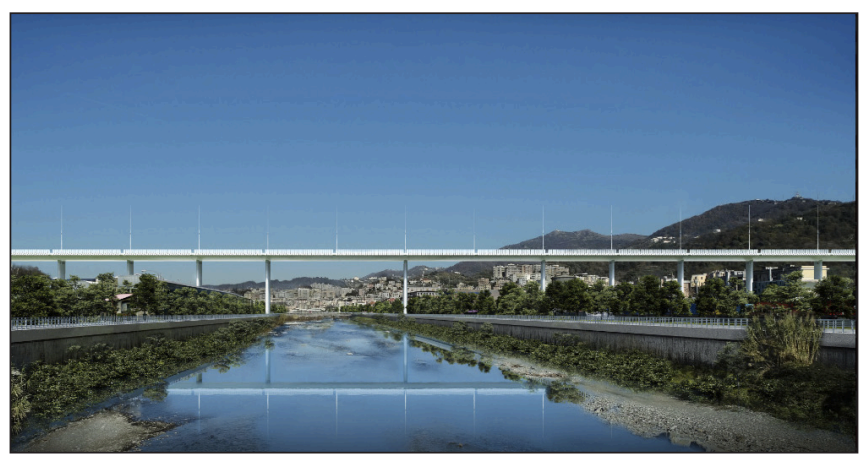

3. ábra Az új hid Genovában (Renzo Piano terve), www.baunetz.de

Az új híd tervét Piano „,egyszerünek, de nem banálisnak“ nevezte (3. ábra). A híd 19 oszlopon fog állni, és a tervek szerint acélból épül, és napelemek segítségével éjszakánként 43 lámpa fog világítani, ahonnan hatalmas vitorlák formájában a fény az autópálya-híd sávjaira esik. Ezzel Piano a Morandi-híd összeomlásakor meghalt 43 áldozatnak akar emléket állítani.

Renzo Piano ígéri, hogy acélszerkezete „ezer évig tart“. A viadukt, ami enyhén áthidalja a Polcevera folyó völgyét, élénk színekkel fog világítani. A híd alatt nem építenek több lakóépületet, ehelyett parkokat és sportlétesítményeket terveznek. Mellékesen jegyezném meg, hogy a lebontás és újjáépités legalább 220 millió eurós költségét az Autostrade autópálya-üzemeltető és az Atlantia Benetton holding viseli.

2019 junius 28: felrobbantották az összeomlott Genovai híd maradványait. A Genovai híd fennmaradó oszlopai egy hatalmas porfelhőben összeomlottak egy elöre tervezett robbantás során (4. és 5. ábra).

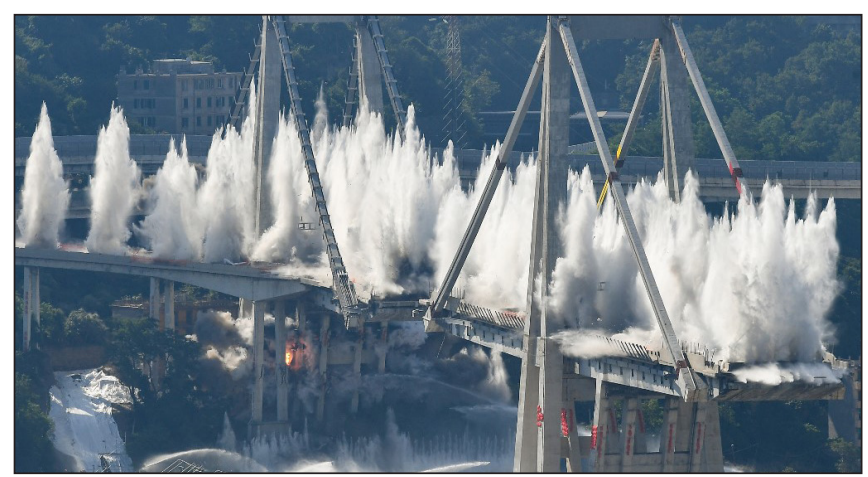

4. ábra: A Morandi-Viadukt vége (c) keystone-sda.ch
2019. augusztus 14: Az olasz la Repubblica (https://genova. repubblica.it/) közzétette a Morandi-híd összeomlásának egyéves évfordulóján Roberto Orlando újságíró egy évig tartó munkáját, egy szekvenciába helyezett fotosorozatot, amelyet újságíró az egyes hónapok 14. napján készített. A genovai újságíró munkája addig folytatódik, amíg az új híd meg nem épül.

A képek megkisérlik dokumentálni az összeomlás „előtti és utáni” különbségeket, és homogén módon leírni a Genova számára létfontosságú infrastruktúra lebontásának és újjáépítésének fejlődését.

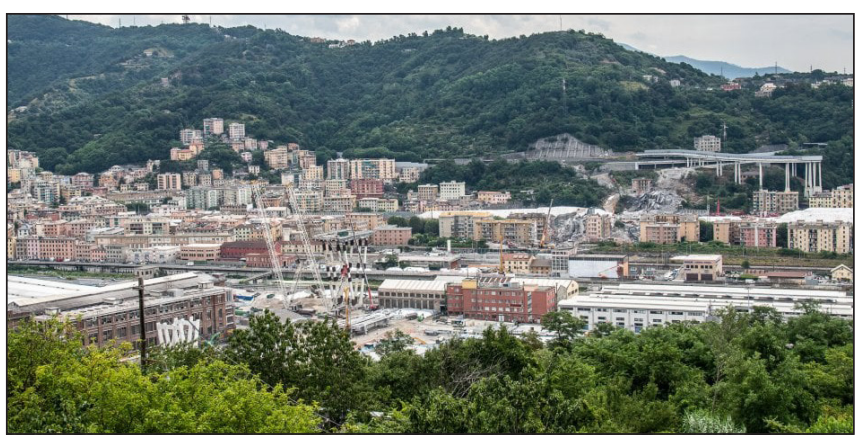

5. ábra: Genovai viadukt a lebontás után (C) Roberto Orlando

2019. október 1: Helyére kerül az új genovai viadukt első darabja (6. ábra). A 45 méter magasságban elhelyezendő, acélból készülö részeket, Nápoly közelében gyártják. Készen szállítják őket Genovába és behelyezik a betonoszlopok közé.

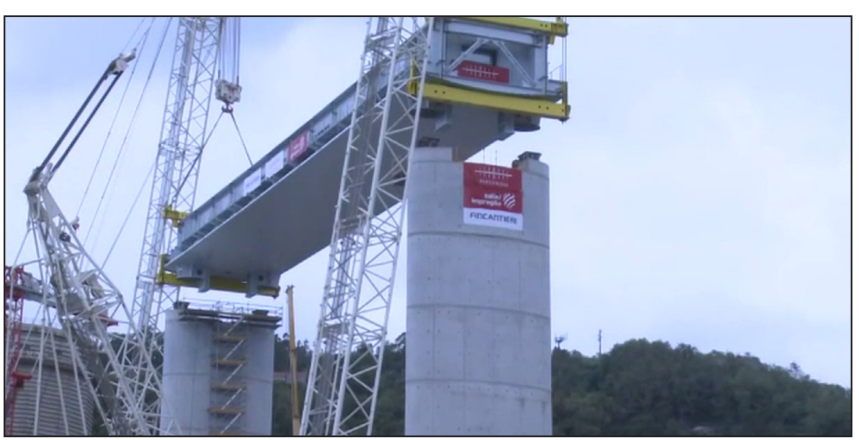

6. ábra: Az épülő új viadukt első darabja

2019. október 16: Stefano Boeri Architetti, a Metrogramma Milan és az Inside Outside megnyeri a genovai Parco del Ponte versenyét. A „Polcevera Park és a Vörös Kör” elnevezésü városi projektet úgy alakították ki, hogy különféle ökológiai és infrastruktúrájú parkok rendszere legyen a fenntartható mobilitás érdekében (7. ábra).

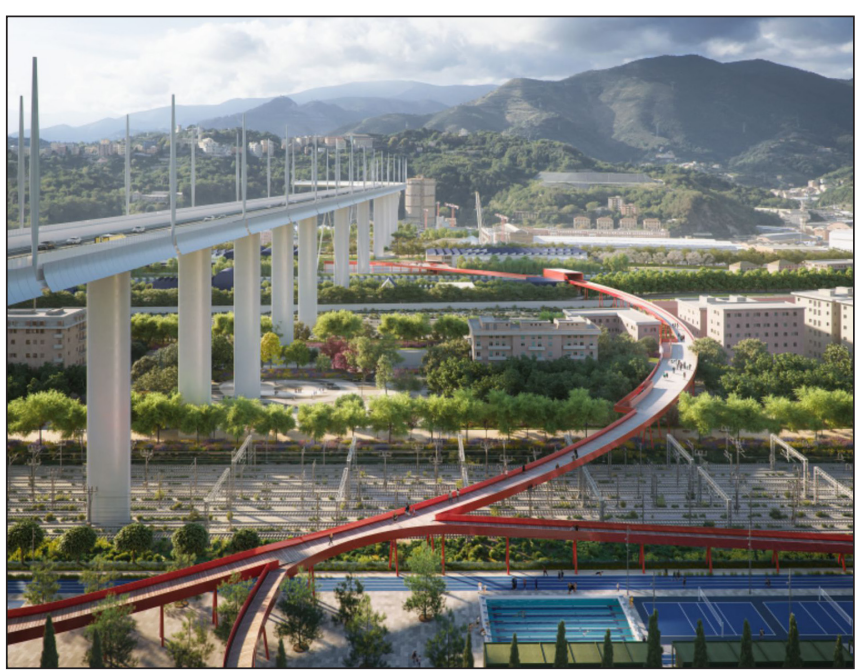

7. ábra: Polcevera Park és a Vörös Kör, (c) Stefano Boeri Architetti 
A sztárépítész Renzo Piano számos épületet tervezett szerte a világon, többek között a berni Paul Klee Központot, a londoni „The Shard”-ot (London Bridge Tower), a New York Times épületét Manhattanben, a ,,The Board” Contemporary Art Museumot Los Angelesben (8.-11. ábrák).

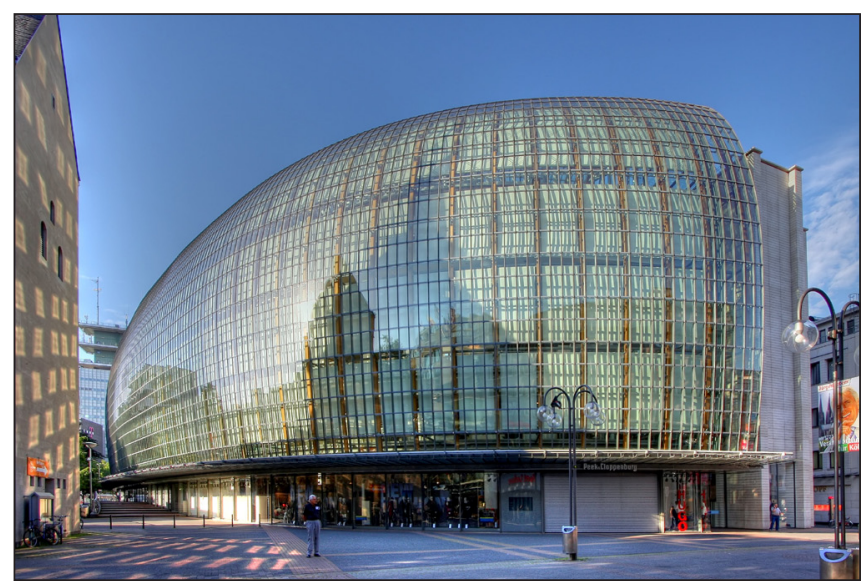

8. ábra: Weltstadthaus, Köln, Wikimedia Commons, CC BY-SA 4.0, Raimond Spekking

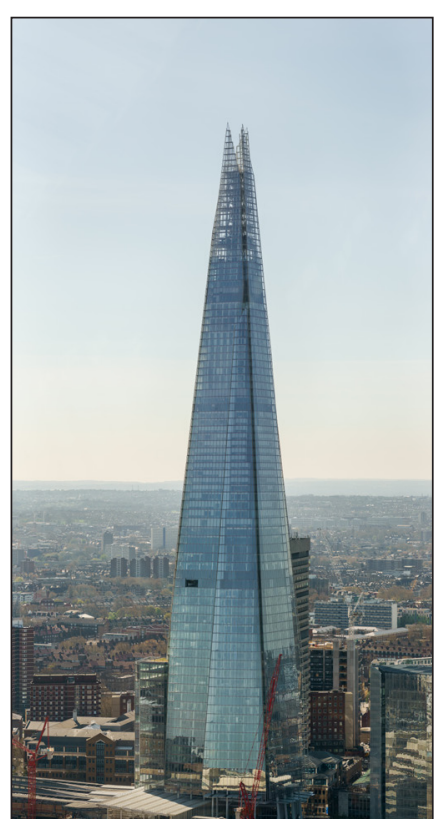

9. ábra: The Shard, London, Wikimedia Commons, CC BY-SA 4.0

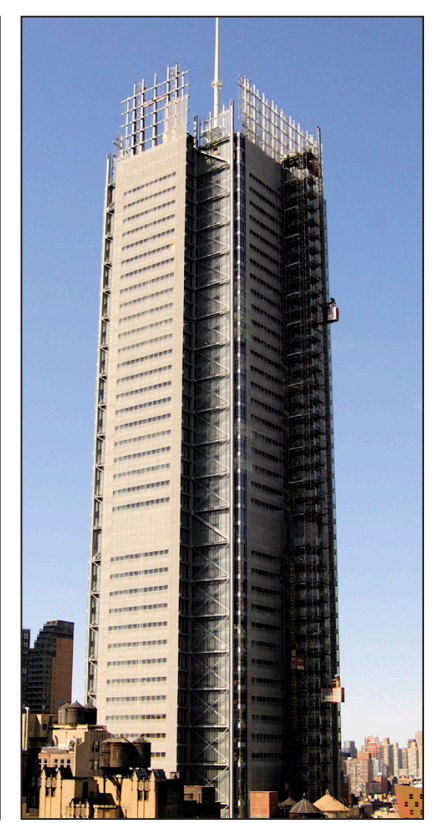

10. ábra: New York Times Tower, CC BY-SA 2.0, Kevin Prichard

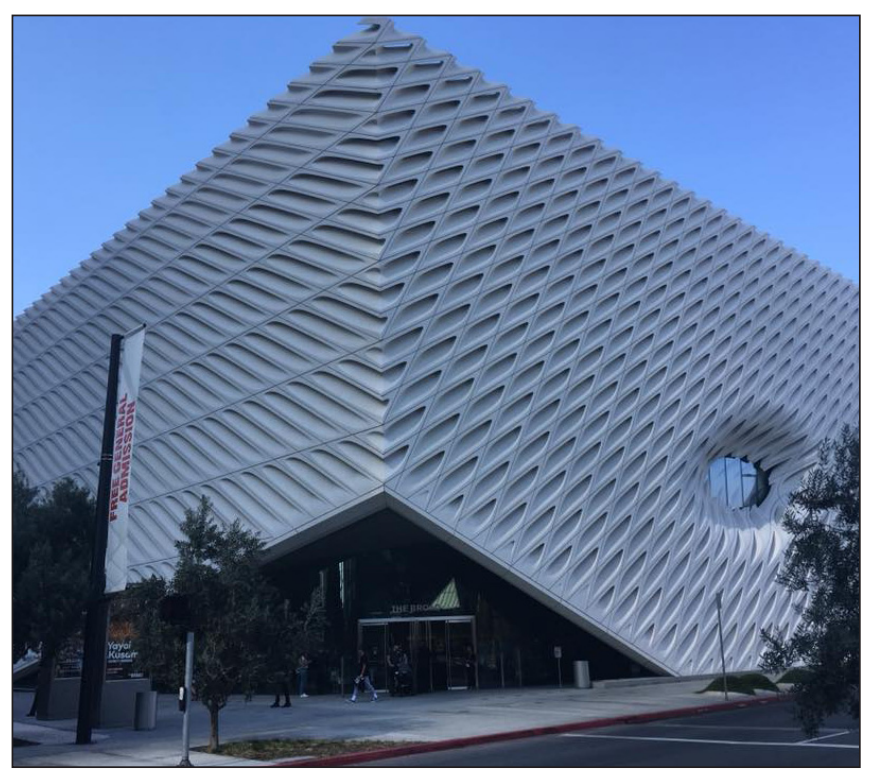

11. ábra: The Board, Los Angeles, Wikimedia Commons, CC BY-SA 4.0, Kerstin Bednarek
Kölnben a Weltstadthaus-ot tervezte Lyonban a „, Cité Internationale-t”. Munkáját egy átfogó elkötelezettség jellemzi, amelyben egyesíti a technológiát, a müvészetet, a kézmüvességet, a természetet és a társadalmi törekvést. Renzo Piano jelenleg genovai, párizsi és berlini tervezőirodáit vezeti, Renzo Piano Building Workshop (RPBW) néven egyesítve. Irodáiban építészek, mérnökök és más szakemberek már évek óta együttmüködnek.

Santiago Calatrava, az építész, szobrász, szerkezetépítő mérnök 1951-ben született Valencia közelében. Építész diplomáját 1975-ben a valenciai Építész- és Iparmüvész Egyetemen (Escuela Técnica Superior de Arquitectura), építömérnöki diplomáját az ETH (Eidgenössische Technische Hochschule) Épitőmérnöki Karán 1979-ben szerezte meg. Calatrava az építészeten túl szobrászattal és festészettel is foglalkozik. 1981-ben ,Zur Faltbarkeit von Fachwerken" címü értekezésével doktori címet szerzett (ETH Zürich).

Santiago Calatrava kétségtelenül sztár. Merészen ívelt épületei a modernitás kifejezését jelentették.

„De a költségek mindig óriásiak voltak, a müvészi értékek ellentmondásosak, és az építési hibák most már híressé váltak" - így számol le a neves építészkritikus Llàtzer Moix a „Calatrava rendszerrel”, „Queríamos un Calatrava” („Calatravát akartunk”) eddig csak spanyolul megjelent könyvében. (Anagrama kiadó)

Spanyolországban - irja Llàtzer Moix - a Calatrava rendszer elérte korlátait. „Calatrava nemcsak itt nőtt fel, hanem azt is kimutatta, hogy ő a nemzetközi sztárépítészek körében kivételes jelenség volt, és egyben immunitást élvez a kritika ellen. Rendíthetetlenül meg van győződve saját zsenialitásáról. Calatrava ívelt függesztett hidjait Barcelonában, Bilbao és Sevilla városokban is megtaláljuk. Kongresszusi - mozgás közben befagyott - központjai mind Oviedóban, Valenciában és Tenerifén is felépültek - egy paradoxon - mondja Moix: a különbségért küzdő városok hasonlóvá váltak”. „A mester rendszeresen törli azokat a kikötéseket, amelyek korlátoznák a további építési költségeket: ez a müvészi szabadságának korlátozását jelentené."

Calatrava egyébként irodákat tart fenn Zürichben, Párizsban, New Yorkban és Valenciában is. Renzo Pianoval ellentétben alkalmazottai láthatatlanok, mesterképzős hallgatók nem léteznek. Moix lesujtó kritikája után tekintsük meg Calatrava néhány - szerintem csodálatos - merész és futurisztikus alkotását.

Az 1985 és 1987 között épült „Pont de Bac de Roda” feltűnő közúti híd Barcelonában, Calatrava első munkája (12. ábra).

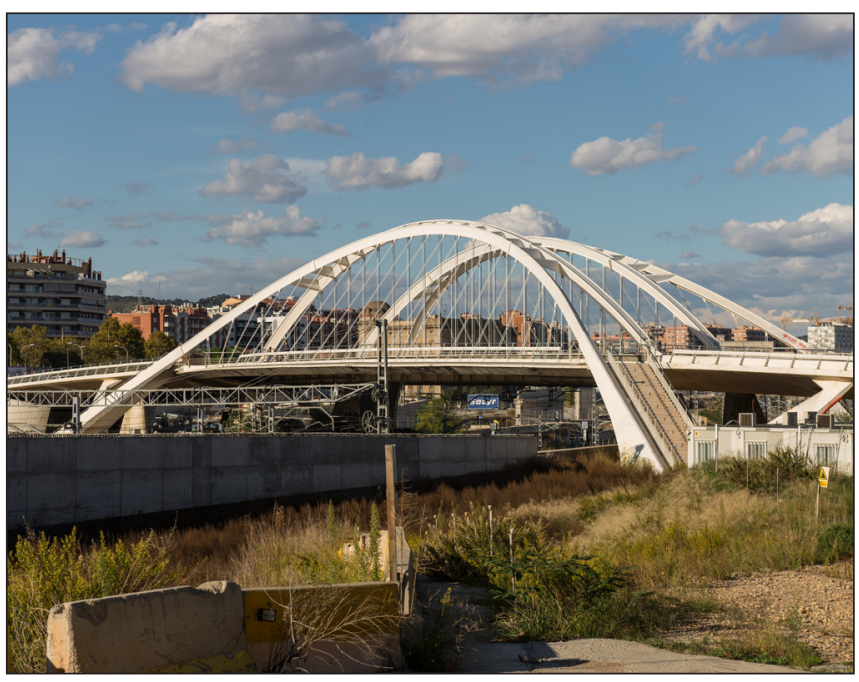

12. ábra: Pont de Bac de Roda, Wikimedia Österreich 
A ferdekábeles Puente del Alamilló híd a Guadalquivir folyót íveli át, ezt Calatrava az 1992-es Expo számára tervezte (13. ábra). Ez volt a világ első olyan ferdekábeles hídja, amelynek nincsenek hátsó kábelei. A hidat eredetileg kettős hídként tervezték. Pénzhiány és a nagyon drága konstrukció miatt azonban csak egy híd épült.

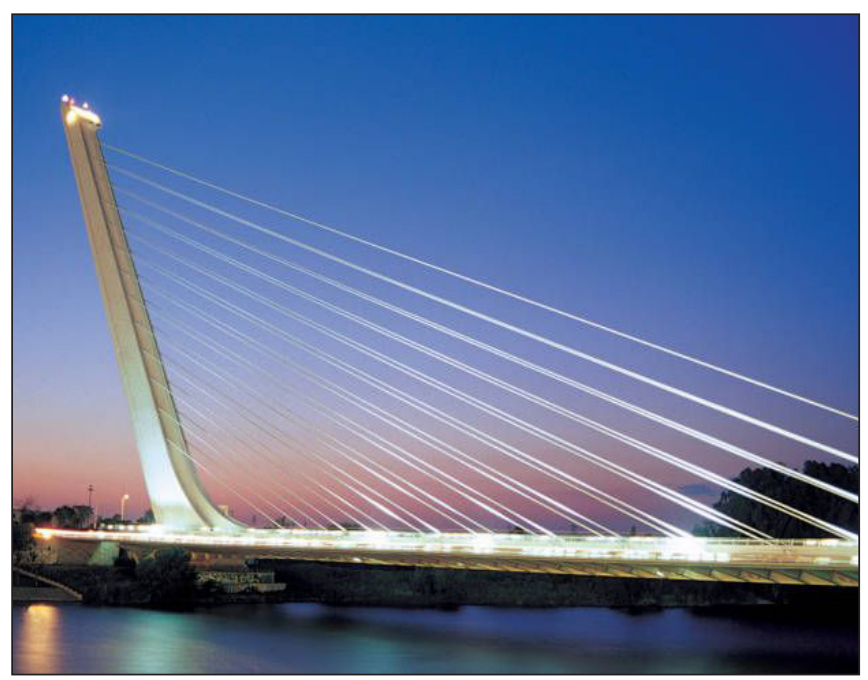

13. ábra: Alamillo hid, Sevilla @ B Bernd Nebel

A spanyol iparváros, Bilbao 30000 euró kártérítést fizetett Santiago Calatrava építésznek, mivel az ő hozzájárulása nélkül építették át az 1997-ben átadott gyalogoshidat (14. ábra). (Calatrava eredetileg 3 milliót követelt, mert a város megsértette a szerzői jogát.) A híd kezdettől fogva kritizálásra került: nem volt praktikus, bírálták. Az üveglapok rossz időjárás esetén csúszósak lettek. Hasonló problémák merültek fel a 2008 ban átadott a Canal Grandét átívelö „Ponte della Costituzione" hiddal Velencében. Az olasz médiák jelentése szerint Calatravát 78.000 Euro kártérítésre itélték el ezévben gondatlan tervezésért.

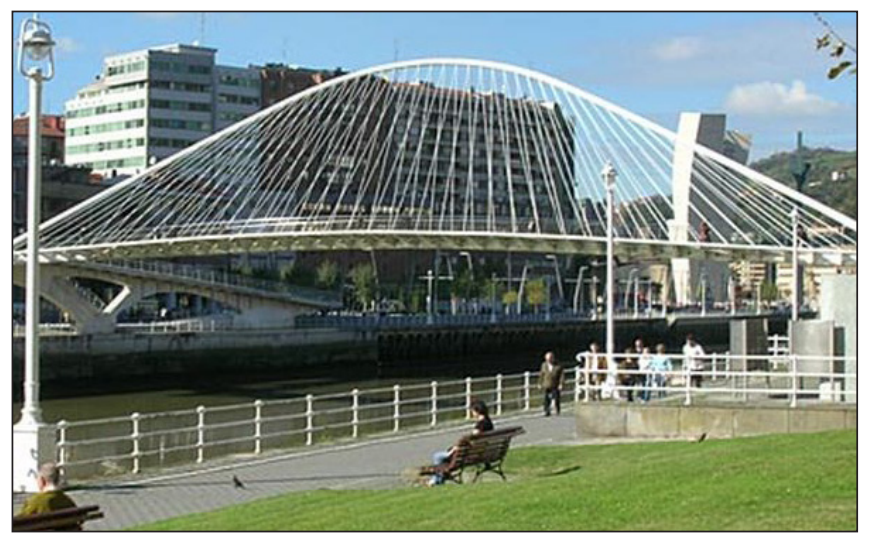

14. ábra: Gyalogoshid, Bilbao, (c) Wikimedia Commons (Dovidena)

Az 2003-ban elkészült „,Auditorio de Tenerife Adán Martín" (korábbi, de még mindig elterjedten használt elnevezésén Auditorio de Tenerife) a Spanyolországhoz tartozó Kanári-szigetek Santa Cruz de Tenerife városában található előadóterem és müvészeti központ (15. ábra). (Kicsit emlékeztet a dán építész Jørn Utzon által tervezett sydney-i Operaházra).

2005-ben, multimédiás látványossággal és hatalmas tüzijátékkal ünnepelte Valencia a „Palau de les Arts Reina Sofia" (Zsófia királyné Müvészetek Palotája) megnyitását, amely 1,3 milliárd euróval, háromszorosával került többe a tervezettnél (16.ábra). 2013. végén a kerámia burkolat egyes részeit lehullottak, így a régió kormánya elrendelte az ideiglenes bezárást.

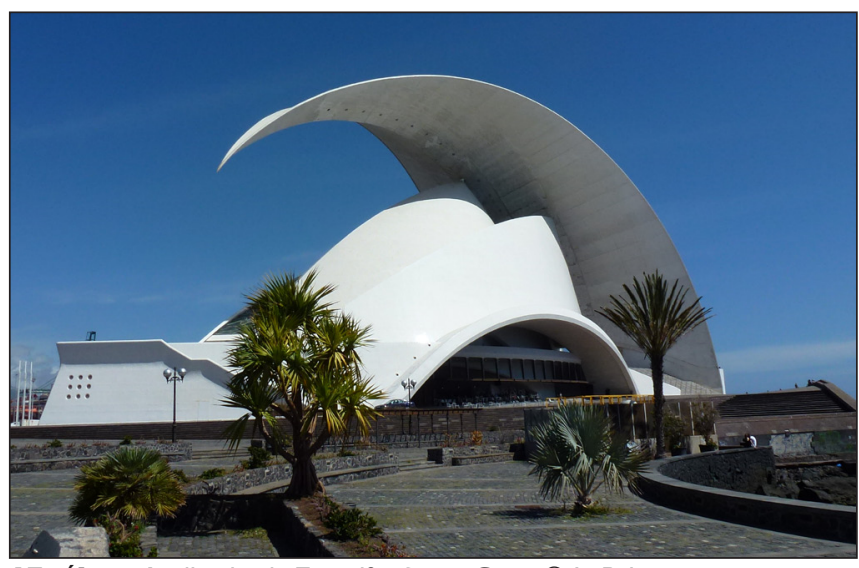

15. ábra: Auditorio de Tenerife, Santa Cruz, (C) L. Palotas

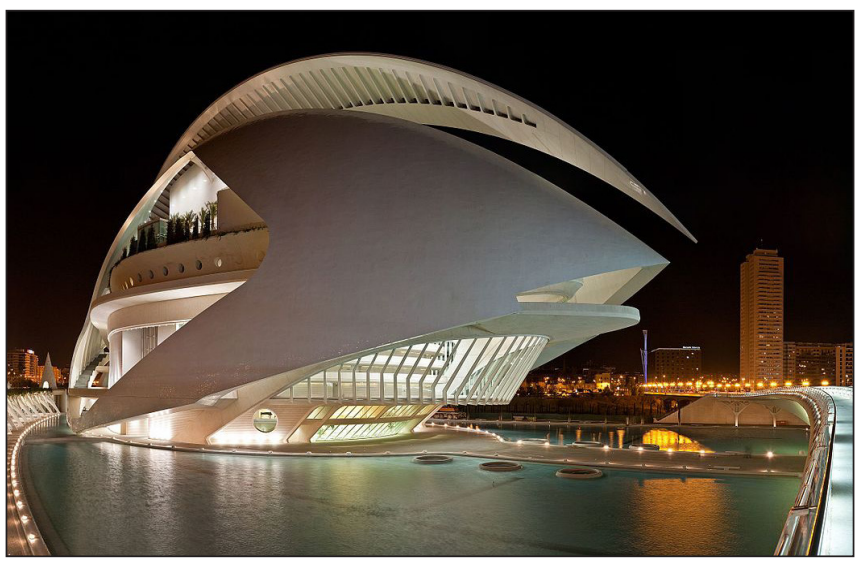

16. ábra: Palau de les Arts Reina Sofía, Valencia, „Photo by DAVID ILIFF. CC BY-SA 3.0"

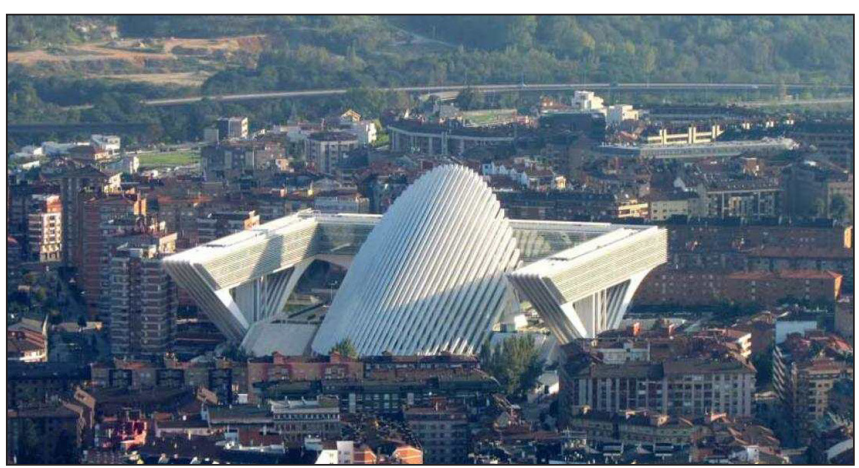

17. ábra: Palacio de Congresos, Oviedo, Flickr/CC/Andres Flores

A Ovideo kongresszusi palotát 2011-ben nyitották meg (17. ábra) 2006-ban a „Palacio de Congresos” tetőelemei összeomlottak. A sztárépítészt 2,96 millió kártérítésre ítélte az oviedoi kerületi bíróság. A Calatrava által tervezett mozgatható tető végül a hidraulikus csúszórendszer problémái miatt nem mozgatható maradt.

2016. március 3-án, a szeptember 11-i terrortámadások helyén, New York-ban, majdnem egy évtizedes késés után nyitották meg a világ legdrágább vasútállomását az „Oculus“-t (18. ábra). Az állomás felépítése csaknem 4 milliárd dollárba került. Ez 2 milliárd dollárval több volt, mint ahogy eredetileg tervezték.

Visszatérve a Morandi-híd újjáépítéséhez:

A ,versenypályázat vesztese”, Santiago Calatrava három projektet fejlesztett ki, melyeket a Friulan Cimolai acélépítő társasággal kellett volna realizálni. A közösségi hálózatok kedvence, Calatrava legambiciózusabb terve, egy látványos boltíves híd volt, amelyet költségvetési okokból valoszinüleg aligha lehetett volna megvalósítani.

Befejezésül tekintsük meg Santiago Calatrava három 


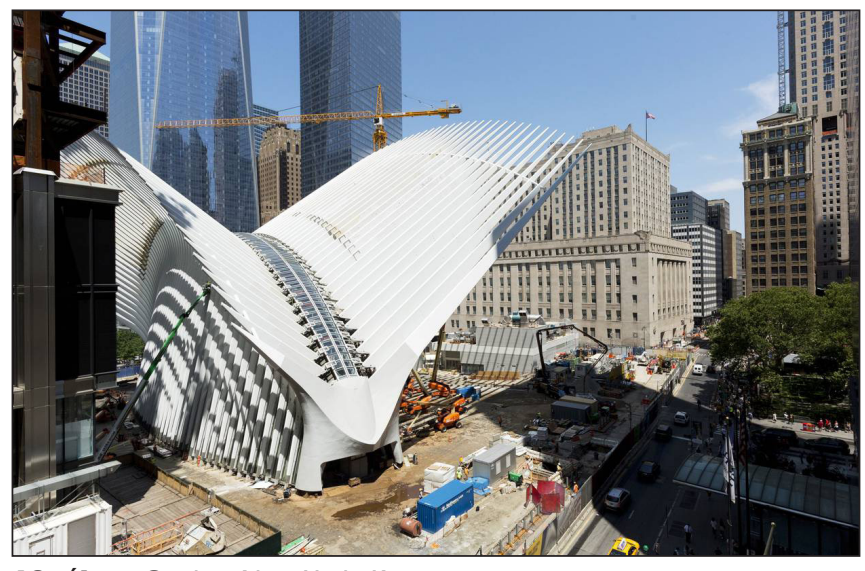

18. ábra: Oculus, New York. Keystoene

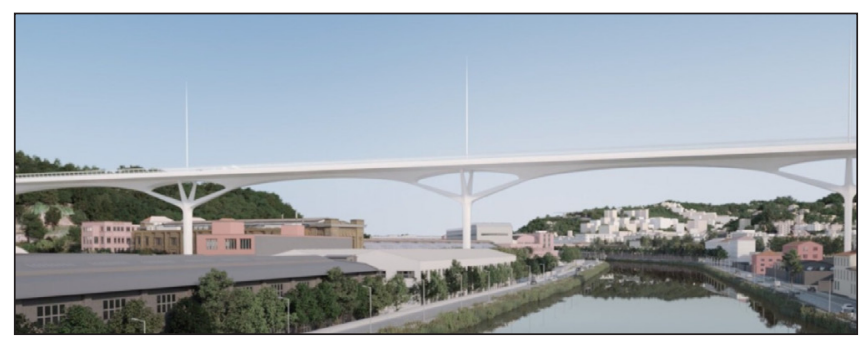

19. ábra: Cristoforo Colombo bridge - Image (C Santiago Calatrava

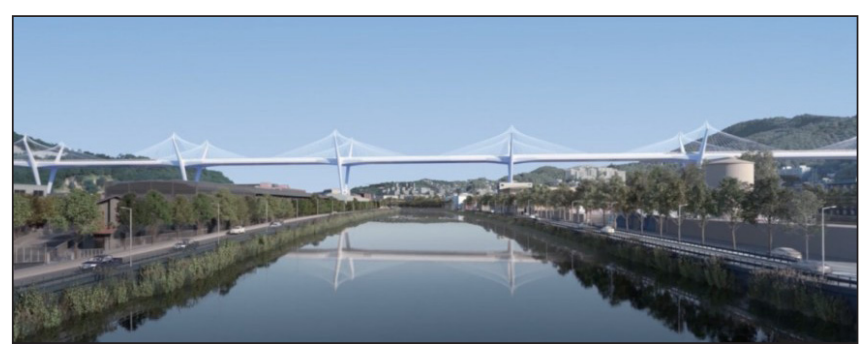

20. ábra: Ponte dei pescatori - Image (C) Santiago Calatrava

tervét a Morandi-hid újjáépitésére (19.-21. ábrák). Az első, a Cristoforo Colombo híd, a második a „Ponte dei pescatori”, egy 140 méter támaszközü kábelhíd.

A harmadik projekt a „Porta Mediterranea II”. Egy nagy ív a Polcevera patakra néz, és folytonosságot teremt a közeli hegyek profiljával.

Tisztelt Dijazottak, nagy örömmel gratulálok a Palotás László-díj odaítéléséhez. A díj ebben az évben is méltó gazdákra talált. Végezetül engedjék meg, hogy a mérnöki, a tudományos és a müszaki problémák megoldásához, a jövőben is sok sikert, alkotóerőt és mindenek előtt jó egészséget kívánjak.

\section{Köszönöm megtisztelö figyelmüket!}

Prof. Dr.-Ing. Laszlo M. Palotas, Ph.D.

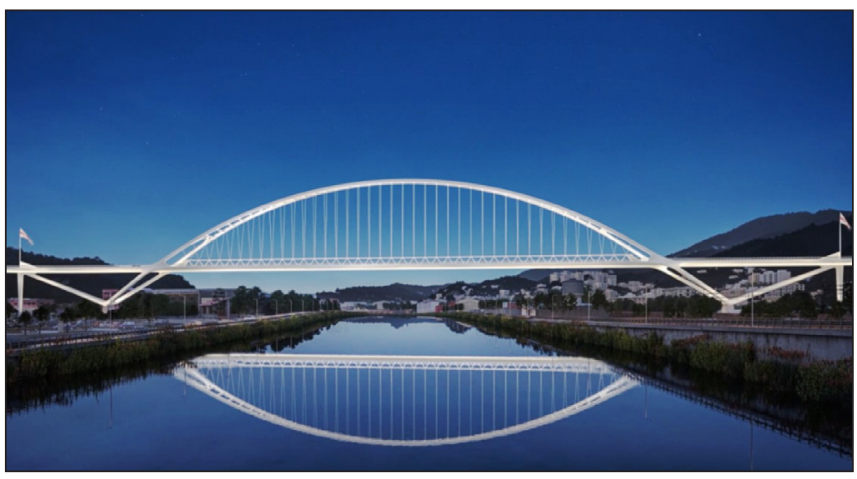

21. ábra: Porta Mediterranea II - Image (C) Santiago Calatrava

\section{HIVATKOZÁSOK}

https://genova.repubblica.it/cronaca/2019/08/14/

http://arkviz.net/

http://aasarchitecture.com/

http://www.ppan.it

http://www.ppan.it/stories/genova-parco-boeri/

https://www.archdaily.com/

https://www.nzz.ch/international/renzo-piano-soll-genuas-neue-brueckebauen-ld.1446138

https://www.handelszeitung.ch/

Jodidio, Philip: Piano. Complete Works 1966-today, 2017, Taschen

Jodidio, Philip: Calatrava. Complete Works 1979-Today, 2018, Taschen

https://calatrava.com

Llátzer Moix: Queríamos un Calatrava!, Anagrama S.A., 2016

https:/www.deutschlandfunk.de/architekt-calatrava-in-der-kritik-esbroeckelt.807.de.html?dram:article id $=373860$

https://hu.wikipedia.org/wiki/Santiago_Calatrava

https://www.handelszeitung.ch/vermischtes/new-york-calatravas-bahnhofist-endlich-eroeffnet-1009594

https://www.handelszeitung.ch/vermischtes/new-york-calatravas-bahnhofist-endlich-eroeffnet-1009594

https://wsimag.com/es/arquitectura-y-diseno/20378-la-ciudad-de-las-artesy-las-ciencias

https://de.wikipedia.org/wiki/Polcevera-Viadukt

www.rpbw.com

https://de.euronews.com/2018/12/19/genua-neubau-der-katastrophenbrucke https://www.zpk.org/de/service-navigation/ueber-uns_0/architektur/renzopiano-108.html

http://epiteszforum.hu/egy-evvel-a-katasztrofa-utan-mi-tortent-a-morandihiddal

https://www.sueddeutsche.de/autoren/carolin-gasteiger-1.1408503 